\title{
Notes on Succession in Old Fields in Southeastern Ontario: the Herbs
}

\author{
A. Crowder ${ }^{1,3}$, R. HARMSEn ${ }^{1}$, and S. E. BlatT ${ }^{2}$ \\ ${ }^{1}$ Department of Biology, Queen's University, Kingston, Ontario K7L 3N6 Canada \\ ${ }^{2} 6$ Wallace Place, Wolfville, Nova Scotia B4P 2R6 Canada \\ ${ }^{3}$ Corresponding author
}

Crowder, A., R. Harmsen, and S. E. Blatt. 2007. Notes on succession in old fields in southeastern Ontario: the herbs. Canadian Field-Naturalist 121(2): 182-190.

\begin{abstract}
Vegetation in abandoned hayfields was monitored during 1976-1998. An earlier successional stage followed ploughing. Changes in tree, shrub and vine populations have been reported earlier and showed expected increases in species richness and cover. Highest species richness of herbs occurred three years after ploughing. Non-woody species richness trended irregularly downward, while non-woody cover was variable, peaking in 1987. Within the herbaceous community, year-toyear changes in cover and frequency of species in the following selected groups are reported here: 18 grasses including sown and adventive species; 13 legumes including two sown species; 14 macroforbs of the Compositae, including a goldenrod, Solidago canadensis, which dominated parts of the fields; a rosette weed, Taraxacum officinalis; sedges, horsetails and some other minor components. Grasses and goldenrods were grazed, sometimes intensively and repeatedly, by insects; grasses were impacted by skipper larvae (Thymelicus lineola), and goldenrods by beetle larvae (Trirhabda spp.). Effects of repeated outbreaks on host plant cover are shown for two plots $\left(100 \mathrm{~m}^{2}\right)$ matching the scale of outbreaks.
\end{abstract}

Key Words: old field herbs, phytophagous insects, plant succession, goldenrods, grasses, legumes, Ontario.

Two abandoned hayfields in southeastern Ontario were selected as sites in which to investigate possible effects of insect herbivory on early stages of secondary succession. The location, geology, history of land use, and soils have been described earlier (Crowder and Harmsen 1998). Their nutrient status was discussed by Epp and Aarssen (1988). Estimates of increasing cover and abundance of trees, shrubs and vines (51 species) during 1976-1998 were shown to follow classic successional models, although with unusual pioneer species. After two decades the structure of the vegetation had become heterogeneous, with groves of small trees, shrub thickets, patches dominated by macroforbs and patches still dominated by grasses. Cover varied with fluctuations of weather from year to year, while soil differences influenced cover and species richness.

Most successional studies on old fields use synoptic records from fields of different ages, a method which obscures minor fluctuations and differences between fields. In this paper, year-to-year observations are used to follow temporal changes in the herbaceous community and to relate its cover and species richness to those of the woody layers. Herbaceous species found in 27 experimental plots are listed to allow comparisons with other areas; lichens and bryophytes are omitted. Differences in soil texture (Crowder and Harmsen 1998) influenced cover and richness.

Within the herbaceous community, details of temporal change in selected groups of plants and some specific interactions are reported here. Grasses were the main constituents of the hayfields, including both agricultural and adventives species. Legumes also included sown and invasive species. Invasive macroforbs, mainly Solidago and Aster species, dominated parts of the fields; population changes of 15 species are reported. Taraxacum officinalis, Dandelion, was selected to represent rosette plants. Sedges, horsetails and a few other minor components are described.

During the decades when vegetation was monitored, arthropods were also sampled (McBrien et al. 1983). Two insect populations had repetitive outbreaks which caused significant decreases of plant cover, and are therefore the only arthropods reported here. Larvae of the hesperiid European Skipper (Thymelicus lineola) grazed on grasses, particularly on Timothy, Phleum pratense (Henderson 1986). Larvae of beetles of the genus Trirhabda Le Conte (Coleoptera, Chrysomelidae), mostly Trirhabda virgata, grazed primarily on leaves of Solidago canadensis, causing intense defoliation. The strong effect of one or more outbreaks of beetles on plant vigour was replicated experimentally (McBrien and Harmsen 1987). These defoliations can cause changes in successional pathways at the grassmacroforb stage by affecting the relative dominance of grass or goldenrods. Blatt et al. (2001) have used these data to develop a successional model including herbivore effects, showing possible outcomes for the herbs.

\section{Methods}

A hayfield abandoned in 1970 and one mown for hay until 1975 were selected at Queen's University Biology Station at Opinicon, Frontenac County, Ontario $\left(44^{\circ} 03^{\prime} \mathrm{N}, 76^{\circ} 0^{\prime} \mathrm{W}\right)$. Nine permanent plots, each $100 \mathrm{~m}^{2}$, were demarcated in 1975 in the older field, which was called S field, for Solidago. Eighteen similar 
plots were placed in the younger field, and nine of these were ploughed once; these ploughed plots were called $\mathrm{P}$ and the undisturbed plots $\mathrm{G}$, for grass. All plant species present in the 27 plots were listed in June and September of sampling years: 1976-1988, 1995, 1998. Cover was estimated using five randomly placed quadrats within each plot; cover values used in this paper were from September (McBrien et al. 1983; Henderson 1986). Each quadrat was $50 \mathrm{~cm} \times 50 \mathrm{~cm}$ in area. Values were compared using Scheffe's mean separation test (Zar 1984; Blatt et al. 2003). Percentage frequency, the number of quadrats in which a species was recorded at a particular time (Mellinger 1972; Eriksson and Jakobssen 1998), was used as a measure of relative abundance (Maycock and Guzikowa 1984).

Nomenclature follows Newmaster et al. (1998); voucher specimens were lodged at the Fowler Herbarium, Queen's University. Lichens, mosses and liverworts have been omitted from this paper.

\section{Results and Discussion}

Species richness of woody species and of herbs per $100 \mathrm{~m}^{2}$ plot, through 1976-1998, is shown in Figure 1. Note gaps in sampling after 1988. Herb richness trended downward with high annual variance while woody species richness increased over time (see Crowder and Harmsen 1998).

The range of species richness was 7-65 in ploughed (P) plots, 6-42 in grass-dominated (G) plots, and 6-33 in Solidago (S) plots. Species richness of herbs and of woody plants in a grass plot (G1) and a ploughed plot (P2) are shown in Figures 2 and 3. Because soil texture was found to be correlated with species richness, the selected plots were matched for texture; both are sandy, with relatively low richness (Crowder and Harmsen 1998). Note the difference in scale between Figures $2 \mathrm{~B}$ and 3B. Species richness peaked in $\mathrm{P} 2$ three years after ploughing when several weedy species were present (cf. Armesto and Pickett 1985).

Herbaceous taxa observed in 27 plots during 19761998 are listed in Table 1, in alphabetical order, with English names added (Newmaster et al. 1998). The closest comparable study site is a 50-year-old field, at Erindale (Toronto area), described by Maycock and Guzikowa (1984), in which $93 \%$ of the species listed at Opinicon were found. Other old fields in Ontario have been described by Lamoureux (1970), Reader (1990) and Reader and Buck (1991). Fewer of the Opinicon species (37\%) were found in abandoned hayfields in New York State described by Mellinger (1972), and only 20\% in old fields in Quebec (Dansereau and Gille 1949). The proportion of introduced species at Opinicon was 37\%, which is higher than the average for the Kingston region (Beschel et al. 1970). They included both crop plants and weeds.

During 1976-1998 the cover value of woody plants for all plots combined increased significantly (Crowder and Harmsen 1998); herbaceous cover, however, did not decrease significantly over time (Figure 1 ). Mean percent cover of non-woody species in 1998 was not significantly different from that in 1988, 1986, 1984, 1978, 1977 and 1976. Years with high cover were 1979, 1980, 1981, 1985, or 1987 (Figure 1). These values suggest that herbaceous cover was related to year-toyear changes in weather or herbivory rather than to a steady increase in shading. No correlations of cover values with available climatic data were found, although the years with low cover had partial droughts that caused soil cracking.

Herb cover in selected plots is shown in Figures 2A and $3 \mathrm{~A}$, with relatively low variance between years. Plot G1 consistently had higher values than P2. The main components of herb cover are discussed in the following section. The hayfields had been sown with Phleum pratense (Timothy) and Poa pratensis (Kentucky Blue Grass), which maintained their frequency after the cessation of mowing (see Table 2). Mellinger (1972) also reported their high frequency in old hayfields in New York. In the Opinicon fields the two species are associated randomly (Epp and Aarssen 1988).

Table 2 lists annual percentage frequency of nine grass species. The most frequent invasive grasses have been Elymus repens, Poa compressa and Calamagrostis canadensis. Other less common invasive grasses, not shown on Table 2, were Bromus inermis ssp. pumpellianus, Echinochloa crusgalli, Elymus trachycaulon ssp. trachycaulon, Muhlenbergia mexicana, Panicum acuminatum, Poa capillare, Poa annua, Setaria pumila and Setaria viridis. Annual cover of all grass species in all plots varied from a mean of $35 \%$ in 1998 to a mean of $87 \%$ in 1987 . Cover in the $\mathrm{G}$ (grass) plots exceeded $100 \%$ in some years, because layers of two or more species developed. Differences between the three sets of plots were not consistent.

Cover of grasses did not show synchronous trends within sets of plots. Changes in grass cover were not correlated with soil texture; the two plots shown in Figures 2 and 3 were matched for soil texture but the undisturbed plot G1 in Figure 2 had high grass cover and the ploughed plot in Figure 3 had not. A temporal pattern in the grass-dominated plot showed successive peaks three to five years apart followed by declines in cover values. This pattern was typical of grassdominated plots. The disturbed ploughed plot shown in Figure 3 had two less marked peaks and declines. Herbivory was demonstrated by Henderson (1986) to reduce grass cover significantly; he counted larvae of a hesperiid European Skipper (Thymelicus lineola) and found that peaks of larval numbers coincided with low cover of Elymus repens, Phleum pratense and Poa pratensis, and low concentrations of skipper larvae with high grass cover. The grass species differed in their capacity to recover after an insect outbreak, with Phleum pratense being most negatively affected. Outbreak behaviour by the European Skipper has been documented by Pengelly (1961) elsewhere in Ontario. 
TABLE 1. Alphabetic list of herbs recorded within 27 plots during 1975-1998 at two old fields at Opinicon, with English names. Nomenclature follows Newmaster et al. (1998).

Acalypha virginica. Copperleaf

Achillea millefolium ssp. millefolium. Yarrow

Agrimonia gryposepala. Hooked Agrimony

Agrostis gigantea. Redtop

Ambrosia artemisiifolia. Common Ragweed

Anaphalis margaritacea. Pearly Everlasting

Anemone canadensis. Canada Anemone

Antennaria neglecta. Field Pussytoes

Antennaria parlinii. Plantain-leaved Pussytoes

Arctium minus ssp. minus. Common Burdock

Artemisia absinthium. Absinth

Asclepias syriaca. Common Milkweed

Aster cordifolius. Heart-leaved Aster

Aster ericoides. Heath Aster

Aster lanceolatus. Panicled Aster (includes Aster simplex)

Aster lateriflorus. Calico Aster

Aster umbellatus. Flat-topped White Aster

Aster urophyllus. Arrow-leaved Aster

Barbarea vulgaris. Wintercress

Bromus inermis ssp. pumpellianus. Smooth Brome

Calamagrostis canadensis. Canada Blue Joint

Capsella bursa-pastoris. Shepherd's Purse

Carex aurea. Sedge

Carex communis. Common Sedge

Carex debilis. Sedge

Carex foenea. Sedge

Carex gracillima. Filiform Sedge

Carex granularis. Granular Sedge

Carex laxiflora. Slender Sedge

Carex normalis. Normal Sedge

Carex scoparia. Sedge

Carex vulpinoidea. Fox Sedge

Cerastium fontanum ssp. triviale. Common Mouse-ear

Chickweed

Chenopodium simplex. Maple-leaved Goosefoot

Chrysanthemum leucanthemum. Ox-eye Daisy

Cichorium intybus. Chicory

Cirsium arvense. Canada Thistle

Clinopodium vulgare. Wild Basil

Convolvulus arvensis. Field Bindweed

Conyza canadensis. Canada Fleabane

Dactylis glomerata. Orchard Grass

Danthonia spicata. Poverty Oat Grass

Daucus carota. Wild Carrot

Dianthus armeria. Deptford Pink

Echinochloa crusgalli. Echinochloa

Echium vulgare. Blueweed

Elymus repens. Couchgrass

Elymus trachycaulus ssp. trachycaulus. Slender Wheat Grass

Epilobium hirsutum. Hairy Willow Herb

Equisetum arvense. Field Horsetail

Equisetum hyemale. Scouring Rush

Erigeron annuus. Daisy Fleabane

Erigeron philadelphicus ssp. philadelphicus. Common Fleabane

Erigeron strigosus. Lesser Fleabane

Eupatorium maculatum. Joe Pye Weed

Eupatorium perfoliatum. Boneset

Eupatorium rugosum. White Snakeroot

Euthamia graminifolia. Grass-leaved Goldenrod

Fragaria vesca ssp. americana. Wood Strawberry
Fragaria virginiana. Wild Strawberry

Galinsoga quadriradiata. Quickweed

Galium obtusum. Wild Madder

Galium trifidum ssp. trifidum. Small Bedstraw

Gentiana andrewsii. Bottle Gentian

Geranium bicknellii. Bicknell's Crane's Bill

Geum aleppicum. Yellow Avens

Geum canadense. White Avens

Hieracium aurantiacum. Orange Hawkweed

Hieracium piloselloides. King Devil

Hypericum perforatum. Common St. John's Wort

Juncus dudleyi. Dudley's Rush

Lactuca canadensis. Wild Lettuce

Lepidium campestre. Field Peppergrass

Lithospermum officinale. Gromwell

Lobelia inflata. Indian Tobacco

Lycopus americanus. Cut-leaved Water Horehound

Lycopus uniflorus. Water Horehound

Lysimachia terrestris. Yellow Loosestrife

Medicago lupulina. Black Medick

Medicago sativa ssp. sativa. Alfalfa

Medicago sativa ssp. falcata. Medick

Melilotus alba. White Sweet Clover

Melilotus officinalis. Yellow Sweet Clover

Mentha arvensis ssp. borealis. Wild Mint

Muhlenbergia mexicana. Dropseed

Oenothera perennis. Sundrops

Onoclea sensibilis. Sensitive Fern

Osmunda regalis. Royal Fern

Oxalis stricta. Yellow Wood Sorrel

Panicum acuminatum. Woolly Panic Grass

Panicum capillare. Witch Grass

Panicum depauperatum. Starved Panic Grass

Phleum pratense. Timothy

Physalis heterophylla. Clammy Ground Cherry

Plantago lanceolata. Narrow-leaved Plantain

Plantago major. Common Plantain

Plantago rugelii. Rugel's Plantain

Poa апnua. Annual Blue Grass

Poa compressa. Canada Blue Grass

Poa pratensis ssp. pratensis. Kentucky Blue Grass

Polygonum convolvulus. Black Bindweed

Polygonum persicaria. Lady's Thumb

Polygonum sagittatum Arrowleaved Tear-Thumb

Potentilla argentea. Silvery Cinquefoil

Potentilla canadensis. Old Field Cinquefoil

Potentilla inclinata. Downy Cinquefoil

Potentilla norvegica. Rough Cinquefoil

Potentilla recta. Erect Cinquefoil

Prunella vulgaris ssp. vulgaris. Selfheal

Ranunculus abortivus. Kidney-leaf Buttercup

Ranunculus acris. Field Buttercup

Rudbeckia hirta. Black-eyed Susan

Rumex acetosella ssp. acetosella. Sheep Sorrel

Rumex crispus. Curly Dock

Sanicula marilandica. Black Snakeroot

Setaria pumila. Yellow Foxtail

Setaria. viridis. Green Foxtail

Silene vulgaris. Bladder Campion

Sisymbrium officinale. Hedge-Mustard

Sisyrinchium angustifolium. Blue-eyed Grass

Solidago caesia. Blue-stemmed Goldenrod 
Solidago canadensis. Canada Goldenrod

Solidago gigantea. Tall Goldenrod

Solidago juncea. Early Goldenrod

Solidago nemoralis ssp. nemoralis. Gray Goldenrod

Solidago rugosa. Rough-stemmed Goldenrod

Sonchus asper ssp. asper. Spiny Sow-thistle

Spiranthes romanzoffiana. Hooded Ladies' Tresses

Stellaria borealis ssp. borealis. Northern Stitchwort

Stellaria graminea. Stitchwort

Stellaria media. Chickweed

Taraxacum officinale. Dandelion

Teucrium canadense ssp. canadense. Germander

Thlaspi arvense. Field Pennycress
Tragopogon dubius. Goatsbeard

Tragopogon pratensis ssp. pratensis. Showy Goatsbeard

Trifolium aureum. Yellow Clover

Trifolium campestre. Smaller Hop Clover

Trifolium hybridum. Alsike Clover

Trifolium pratense. Red Clover

Verbascum thapsus. Common Mullein

Verbena hastata. Blue Vervain

Veronica serpyllifolia ssp. serpyllifolia. Thyme-leaved

Speedwell

Vicia cracca. Cow Vetch

Vicia sativa ssp. nigra. Common Vetch

Vicia tetrasperma. Slender Vetch

Viola sp. Violet
Larval outbreaks are considered to affect the successional pathway in the Opinicon fields in a model developed from our data by Blatt et al. (2001). When insect herbivory on grasses in old fields was studied by Brown et al. (1988), Elymus repens was the grass species most affected by Homoptera/Auchenorrhycha; these authors considered that both texture and structure of the successional vegetation were affected by the insects.

The initial seed mix contained Medicago sativa ssp. sativa (Alfalfa) and possibly Trifolium pratense (Red Clover) which have persisted in the fields. Medicago sativa frequency was 3-5\% in 1976-1980, rose to $12 \%$ in 1983 and fell again to $2 \%$ in the 1990s. Trifolium pratense frequency was $35 \%$ in 1976, fell to less than 8\% during 1980-1995 and rose again to 22\% in 1998. Trifolium aureum, Trifolium campestre and Trifolium hybridum were recorded occasionally.

Vetches (Vicia sativa ssp. nigra, Vicia cracca, and Vicia tetrasperma) became more frequent in later years with a maximal frequency of $69 \%$ for Vicia cracca in 1987. Possibly these straggling plants benefited from the cessation of mowing. Other legumes recorded were Melilotus alba, Melilotus officinalis and Medicago lupulinus, randomly distributed except for Medicago lupulina, which was most frequent in 1976-1979 in the ploughed plots.

Macroforb areas of the fields have been and are dominated by Solidago canadensis (Canada Goldenrod), which we observed to spread by both seeds and rhizomes. Its importance in old field succession in North America has been widely reported (e.g., Dale et al. 1966; Goldberg and Gross 1988). Percentage frequency of Solidago canadensis in all plots during 1976-1998 is shown as mean values in Table 2, starting with minimal values in 1976 and reaching a maximum in 1987-1988. Frequencies of Solidago nemoralis (Old Field Goldenrod), Solidago caesia (Blue-stemmed Goldenrod), and Euthamia graminifolia (Grass-leaved Goldenrod), also given in Table 2, were higher in the 1980 s than in the 1970s or 1990s. When the three sets of plots were compared, Solidago canadensis and Soli- dago caesia were found to be most frequent in the $\mathrm{S}$ plots (during 1976-1998 the mean frequency of Solidago canadensis in S plots was $47 \%$, in the $\mathrm{P}$ plots $37 \%$ and in the G plots $26 \%$ ). Solidago nemoralis and Solidago juncea were generally more frequent in sandy dry plots. This distribution may be explained by different soil moisture tolerances among the congeners (Werner and Platt 1976).

Cover values for Solidago canadensis ranged from 1 to $100 \%$. Patterns were not synchronous between plots. Two examples are shown. Figure 3 shows Plot $\mathrm{P} 2$, with three irregular peaks of goldenrod cover, and Figure 2 shows Plot G1 with only three years of sporadic goldenrod cover. The plot with three peaks and lows (Figure 3 ) had a periodicity also observed in other plots, while others had one, two, or three-and-a-half episodes. Some sandy plots similar to that shown in Figure 2 failed to develop dense Solidago cover, and did not have a series of highs and lows.

We have found that the cover of Solidago canadensis was negatively and significantly correlated with larval density of three species of Trirhabda beetles in the field (McBrien et al. 1983; Blatt et al. 2001). Trirhabda virgata was most abundant. Field experiments showed that effects on biomass and cover similar to those caused by larval grazing could be produced by manual defoliation (McBrien and Harmsen 1987).

Within a field, beetle outbreaks were not synchronous between plots. Outbreaks in the two fields also occurred at different times. In the P/G field, years with several plot peaks of Solidago cover were 1980, 1981, and 1985, and years with most lows were 1976, 1985 and 1998. That both peaks and lows occurred in 1985 shows the small scale of the beetle outbreaks, sometimes confined to a plot $100 \mathrm{~m}^{2}$. Outbreaks on a much larger scale have been reported, for example, on a scale of several hectares (Werner et al. 1980), and over two hundred insect species have been reported on Solidago canadensis.

Macroforbs growing to the same size as some goldenrods included the asters Aster umbellatus (Flattopped White Aster) and Aster novae-angliae (New 


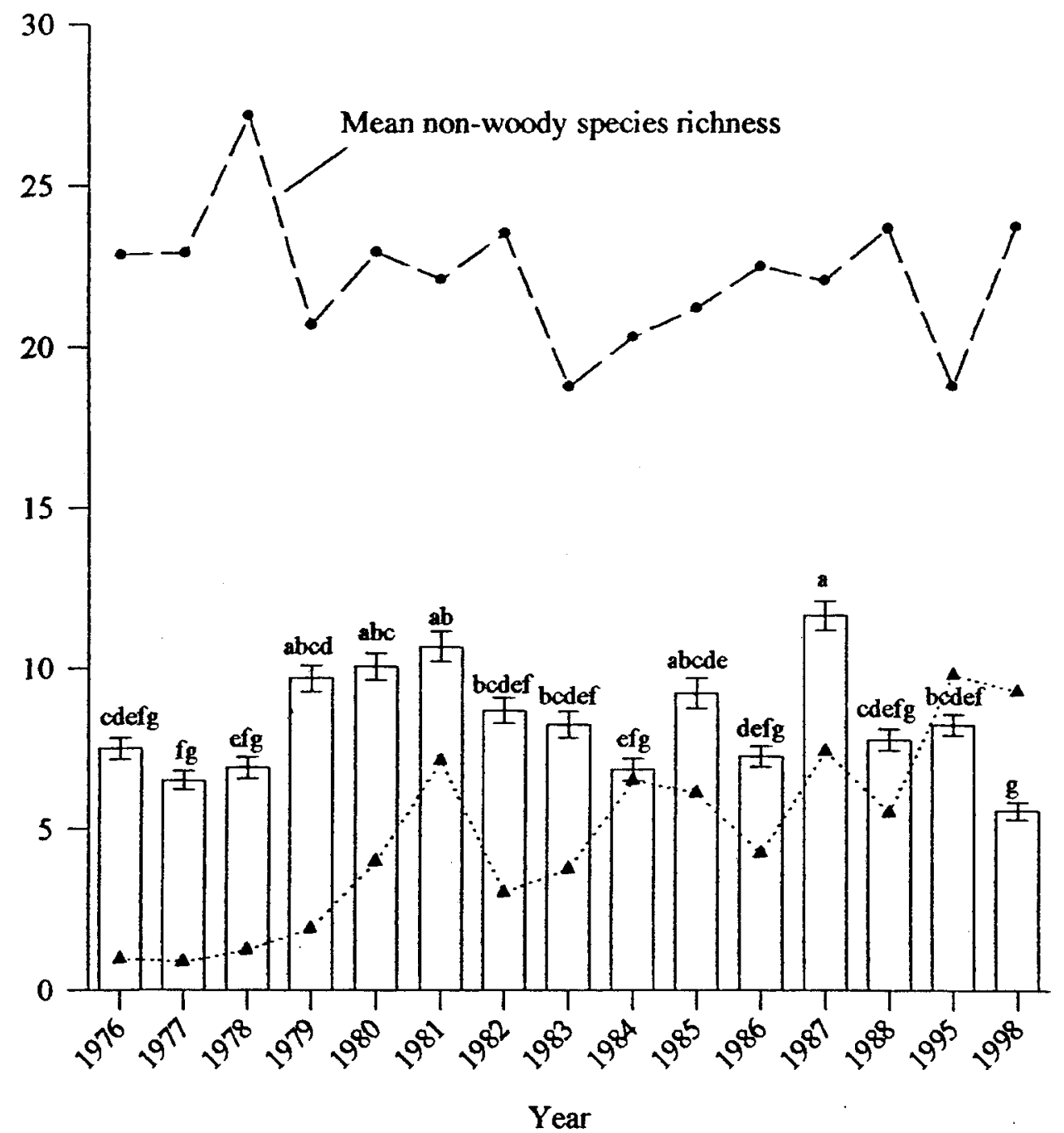

$\square$ Mean percent cover of non-woody species, all plots $\Delta . . . .$. Mean percent cover of woody species, all plots

FIGURE 1. Comparison of woody and non-woody vegetation. Mean species richness of herbaceous plants in 27 plots (species number/100 m²) for the years 1976-1988, 1995 and 1998 is shown by dots. Mean percent cover of non-woody species in all plots in September is shown in the histogram; means which do not share the same letter are significantly different. Mean percent cover of woody species in all plots is indicated by a dotted line with triangles.

England Aster). During the years of observation the percentage frequency of these two species increased (Table 2). Three smaller species, Aster lanceolatus (included in Aster simplex in Table 2), Aster lateriflorus and Aster ontarionis, have been lumped together because they were generally intermingled in straggling clumps which also increased in frequency. Aster cordifolius (Heart-leaved Aster) and Aster urophyllus (Arrow-leaved Aster), both of which are shade-tolerant (Semple et al. 1996), had low frequency. Five of the aster species found in the Opinicon fields were recorded by Maycock and Guzikowa (1984).

When all aster species are lumped together, mean annual cover ranged from 1 to $45 \%$. Comparing dif- 


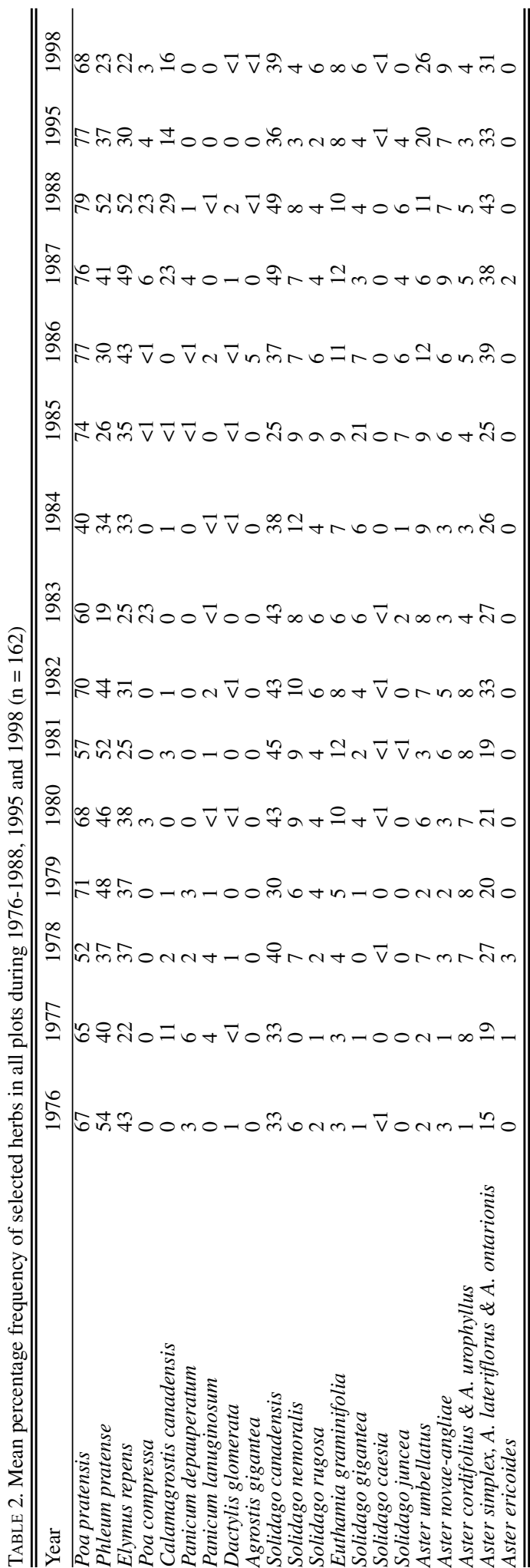

ferent plots, patterns of peaks and lows like those observed in Solidago canadensis occurred in some plots, but with a longer periodicity ranging up to ten years. Since these fluctuations in cover were not synchronous between plots or fields, it is possible that they were due to herbivory, like the changes in Solidago and grasses.

Two species of horsetail, Equisetum arvense and Equisetum hyemale, were present in the $\mathrm{P} / \mathrm{G}$ field throughout 1976-1998 with a combined mean percentage frequency of $68 \%$. Both species were most frequent in sandy plots and are locally common in disturbed habitats such as sandpits (Crowder et al. 1997). Cover did not exceed $29 \%$ for the two species combined in any year, and was generally low.

Mean frequency of Taraxacum officinale ranged from $13 \%$ in 1981 to $37 \%$ in 1988 . Dandelions were present in all three sets of plots every year, with highest frequency in the $S$ and lowest in the $G$ plots. The rosette growth form of Taraxacum officinale is similar to that of many genera in the plots, such as Hieracium spp. and Antennaria parlinii, and probably facilitates early spring growth.

Sedges, Carex spp., were observed in all years and in all sets of plots, but were not analysed because of difficulty in distinguishing non-flowering stages. Carex granularis, Carex laxiflora and Carex normalis were relatively abundant. Mean annual frequency of all species was $39 \%$ and most plants were found in plots with high moisture content (Crowder and Harmsen 1998). Mean cover was less than $2 \%$ until 1979 , rose to $7 \%$ in 1987, and then declined again.

Species which increased in both frequency and cover during 1976-1998 included Asclepias syriaca (Milkweed) and Ranunculus acris (Field Buttercup). Species which declined in both frequency and cover included Rumex acetosella ssp. acetosella (Sheep's Sorrel), Ambrosia artemisiifolia (Ragweed), Oxalis stricta (Yellow Wood Sorrel), and Prunella vulgaris ssp. lanceolata (Self-Heal). Rumex acetosella and Ambrosia artemisiifolia, which are weedy species, were mostly in the ploughed plots, whereas Prunella vulgaris was initially concentrated in grass plots. A minor component with low cover value but high frequency (40-50\%) was Potentilla recta (Erect Cinquefoil).

When grass cover was lowered by grazing of Thymelicus lineola, feeding preferentially on Phleum pratense, cover of Solidago and Aster spp. in both fields increased rapidly; they then maintained their dominance at levels equal to that of Poa pratensis, preventing the recovery of Phleum pratense (Henderson 1986; Blatt et al. 2001; Blatt et al. 2003). In addition to interactions between grasses and goldenrods, other layers were affected. For example, when the cover of Solidago canadensis was decreased by the feeding of beetle larvae a chamaephyte, Fragaria virginiana (Wild Strawberry), showed significantly increased cover (McBrien et al. 1983). This finding 

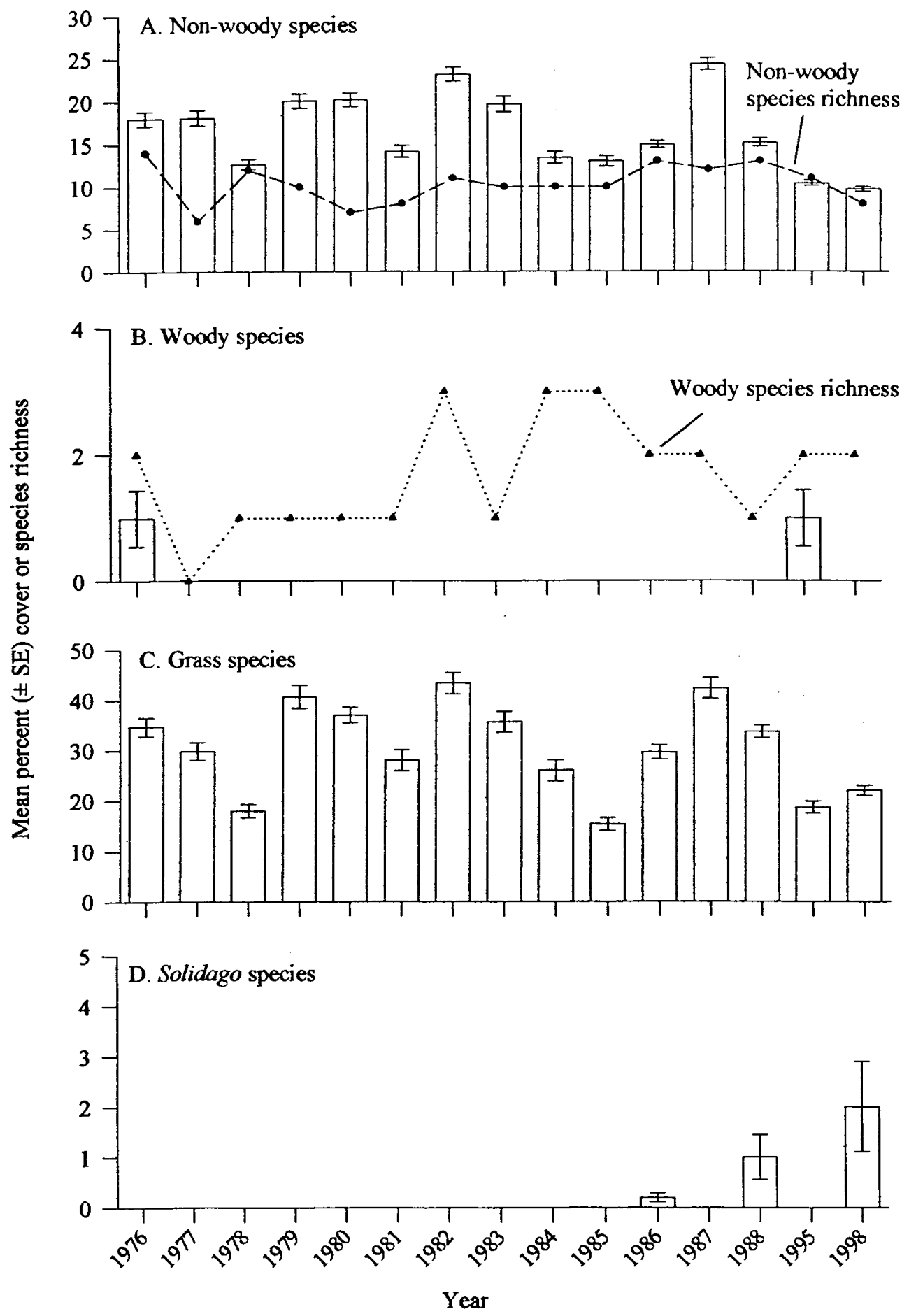

FIGURE 2. Conditions in grass plot G1 during 1976-1988, 1995 and 1998. 2A shows mean percent cover of non-woody species, and non-woody species richness (species number $/ 100 \mathrm{~m}^{2}$ ). $2 \mathrm{~B}$ shows cover and species richness of woody plants. $2 \mathrm{C}$ shows mean cover of all grass species. 2D shows Solidago species cover, which was only present in 1986, 1988 and 1998. 

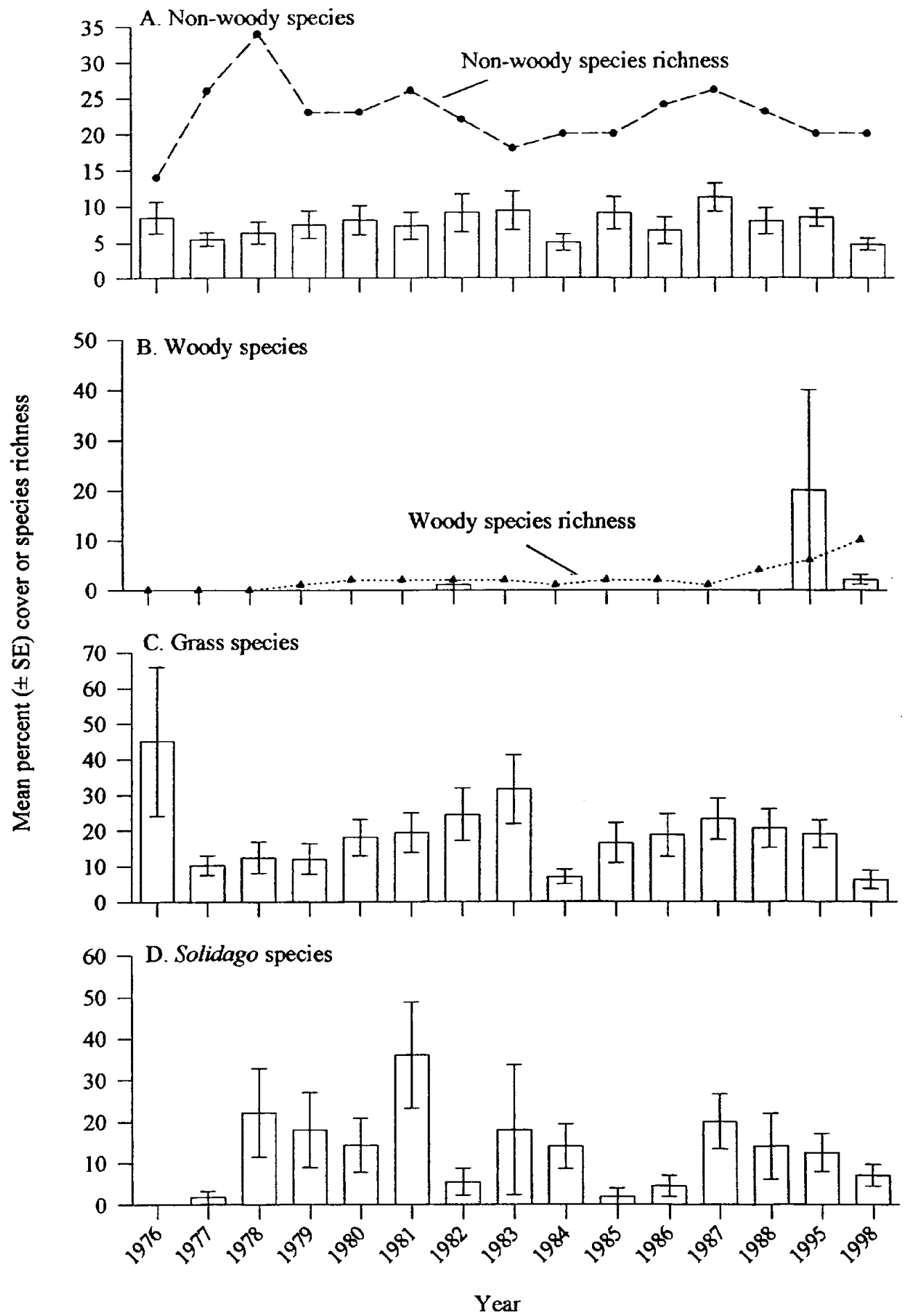

FIGURE 3. Conditions in ploughed plot P2 during 1976-1988, 1995 and 1998. 3A shows non-woody species richness (species/ $100 \mathrm{~m}^{2}$ ) and mean annual percent cover. 3B shows woody species richness and cover. 3C shows cover of all grass species with peaks and lows. 3D shows cover of Solidago species with peaks and lows. 
has been confirmed elsewhere by Carson and Pickett (1990) who attributed it to decreased shading by the macroforb.

Shade-tolerant herbs in the plots included Sanicula marilandica (Black Snakeroot), Teucrium canadense ssp. canadense (Germander), Lactuca canadensis (Wild Lettuce), Solidago caesia and Aster cordifolius. The increase in woody plants documented by Crowder and Harmsen (1998) could have been expected to create conditions favouring increases of such shade-tolerant species. They did not, however, increase in frequency or cover over time. Presumably shaded microniches under plants such as goldenrods were present in early years and were later replaced by similar conditions under shrubs or trees.

\section{Acknowledgments}

Partial funding was received from the Ontario Ministry of Natural Resources; we particularly thank R. Wagner, S. Strobl and P. Neave. Preliminary analysis of field results was done by C. Vardy, and we thank her and the many others who helped with field surveys. Our thanks are due to J. Pringle and P. Catling who identified some of the composites and sedges. We are grateful for the continued support of Queen's University Biology Station.

\section{Literature Cited}

Armesto, J. J., and S. T. A. Pickett. 1985. Experiments on disturbance in old-field plant communities: impact on species richness and abundance. Ecology 66: 230-240.

Beschel, R. E., A. E. Garwood, R. Hainault, I. D. Macdonald, S. P. van der Kloet, and C. H. Zavitz. 1970. List of the vascular plants of the Kingston region. Fowler Herbarium, Queen's University, Kingston, Ontario.

Blatt, S. E., J. A. Janmaat, and R. Harmsen. 2001. Modelling succession to include a herbivore effect. Ecological Modelling 139: 123-136.

Blatt, S. E., J. A. Janmaat, and R. Harmsen. 2003. Quantifying secondary succession: a method for all sites? Community Ecology 4: 141-156.

Brown, V. K., A. C. Gange, and C. W. D. Gibson. 1988. Insect herbivory and vegetational structure. Pages 263-280 in Plant form and vegetation structure. Edited by M. J. A. Werger, P. J. M. van der Aart, H. J. During, and J. T. A. Verhoeven. SPB Academic Publishing, The Hague.

Carson, W. P., and S. T. A. Pickett. 1990. Role of resources and disturbance in an old-field plant community. Ecology 71: 226-238.

Crowder, A., and R. Harmsen. 1998. Notes on forest succession in old fields in southeastern Ontario: the woody species. Canadian Field-Naturalist 112: 410-418.

Crowder A., K. E. J. Topping, and J. C. Topping. 1997. Plants of the Kingston Region: 1996. Fowler Herbarium, Queen's University, Kingston, Ontario.

Dale, H. M., P. J. Harrison, and G. W. Thomson. 1966. Weeds as indicators of physical site characteristics in abandoned pasture. Canadian Journal of Botany 44: 1319-1327.

Dansereau, P., and A. Gille. 1949. Ecologie des principaux types de pâturage des environs de Granby. Bulletin du service de biogéographie. Université de Montréal, Québec.
Epp, G. A., and Aarssen, L. W. 1988. Attributes of competitive ability in herbaceous plants. Pages 71-76 in Plant form and vegetation structure. Edited by M. J. A. Werger, P. J. M. van der Aart, H. T. During, and J. T. A. Verhoeven. SPB Academic Publishing, The Hague.

Eriksson, O., and A. Jakobssen. 1998. Abundance, distribution and life histories of grassland plants: a comparative study of eighty-one species. Journal of Ecology 86: 922933.

Goldberg, D. E., and K. L. Gross. 1988. Disturbance regimes of midsuccessional old fields. Ecology 69: 1677-1688.

Henderson, J. B. 1986. The European Skipper (Thymelicus lineola): population ecology and herbivory in an old-field community. M.Sc. thesis, Queen's University, Kingston, Ontario.

Lamoureux, W. J. 1970. Ecological succession. Garden Bulletin 24. Royal Botanic Gardens, Hamilton, Ontario.

Maycock, P. F., and M. Guzikowa. 1984. Flora and vegetation of an old field community at Erindale, southern Ontario. Canadian Journal of Botany 62: 2193-2207.

McBrien, H., R. Harmsen, and A. Crowder. 1983. A case of insect grazing affecting plant succession. Ecology 65: 1035-1039.

McBrien, H., and R. Harmsen. 1987. Growth response of goldenrod, Solidago canadensis (Asteraceae) to periodic defoliation. Canadian Journal of Botany 56: 1035-1039.

Mellinger, M. 1972. Dynamics of plant succession on abandoned hay fields in central New York State. Ph.D. thesis, University of Syracuse, Syracuse, New York.

Newmaster, S. G., A. Lehela, P. W. C. Uhlig, S. McMurray, and M. J. Oldham. 1998. Ontario Plant List. Ontario Ministry of Natural Resources, Ontario Forest Research Institute, Sault Ste. Marie, Ontario. Information Paper 123.

Pengelly, D. H. 1961. Thymelicus lineola (Ochs) (Lepidoptera: Hesperiidae) a pest of hay and pasture grasses in southern Ontario. Proceedings of the Entomological Society of Ontario 91: 102-105.

Reader, R. J. 1990. Relationship between seedling emergence and species frequency on a gradient of ground cover density in an abandoned pasture. Canadian Journal of Botany 69: 1397-1401.

Reader, R. J., and J. Buck. 1991. Control of seedling density on disturbed ground; role of seedling establishment for some mid-successional old-field species. Canadian Journal of Botany 69: 773-777.

Semple, J. C., S. B. Heard, and C. S. Xiang. 1996. The Asters of Ontario (Compositae: Asteraceae). University of Waterloo Biology Series 38: 1-94. Waterloo, Ontario.

Werner, P. A., I. K. Bradbury, and R. S. Gross. 1980. The biology of Canadian weeds. 45. Solidago canadensis. Canadian Journal of Plant Science 60: 1393-1409.

Werner, P. A., and W. J. Platt. 1976. Ecological relationships of co-occurring goldenrods. (Solidago: Compositae). American Naturalist 110: 959-971.

Zar, J. 1984. Biostatistical analysis. Prentice Hall, Englewood Cliffs, New Jersey.

Received 16 October 2006

Accepted 28 April 2008 